\title{
Culture of the seaweed, Gracilaria tenuistipitata in brackishwater pond and lagoon of Muttukadu, Chennai, Tamil Nadu
}

\author{
SOUMYABRATA SARKAR, P. NILA REKHA, K. AMBASANKAR AND K. K. VIJAYAN \\ ICAR-Central Institute of Brackishwater Aquaculture, 75, Santhome High Road, R. A. Puram, Chennai - 600028 \\ Tamil Nadu, India \\ e-mail: rekha@ciba.res.in,nila_71@yahoo.com
}

\begin{abstract}
In this study, an attempt was made to standardise the method of culture of the seaweed Gracilaria tenuistipitata in brackishwater ecosystems. The species was selected as it is available in abundance due to its tolerance for a wide range of salinity, as seaweed culture in brackishwater ecosystem requires a suitable species which is adaptable and proliferating, An experiment was conducted to estimate the proliferation capacity of $G$. tenuistipitata with different methods of propagation viz., rope culture and net bag culture with different initial biomass intensity $\left(50,100\right.$ and $200 \mathrm{~g} \mathrm{~m}^{-1}$ in rope and 50,100 and $200 \mathrm{~g} \mathrm{~m}^{-2}$ in net bag) in different ecosystems viz., lagoon and pond. The results showed that G. tenuistipitata proliferates in both lagoon and in pond ecosystem, with high SGR in rope culture compared to net bag method. With respect to different initial biomass intensity in rope method, there was no significant difference in specific growth rate (SGR) between $50 \mathrm{~g} \mathrm{~m}^{-1}$ $(12.86 \pm 0.35 \%)$ and $100 \mathrm{~g} \mathrm{~m}^{-1}(10.94 \pm 0.34 \%)$ but it was significantly higher when compared to $200 \mathrm{~g} \mathrm{~m}^{-1}(6.14 \pm 1.1 \%)$ during 20 days of culture in lagoon ecosystem. It was also observed that SGR was significantly higher with $50 \mathrm{~g} \mathrm{~m}^{-2}(7.23 \pm 0.46 \%)$ when compared with $100 \mathrm{~g} \mathrm{~m}^{-2}(5.86 \pm 0.03 \%)$ and $200 \mathrm{~g} \mathrm{~m}^{-2}(5.64 \pm 0.02 \%)$ in net bag culture in pond ecosystem. Moreover, 20 days of culture showed significantly higher SGR with 50 and $100 \mathrm{~g} \mathrm{~m}^{-1}$ than 40 and 60 days of culture period in lagoon ecosystem. It can be concluded that rope cultivation of $G$. tenuistipitata with 50-100 $\mathrm{g} \mathrm{m}^{-1}$ of initial biomass intensity was ideal in lagoon for 20 days of culture at brackishwater salinity regime of 19-25 ppt.
\end{abstract}

Keywords: Brackishwater, Gracilaria tenuistipitata, Initial biomass, Lagoon, Net bag, Rope culture

\section{Introduction}

The interaction between humans and seaweeds has a long history since Neolithic period (Erlandson et al., 2015; Buschmann et al., 2017), but the most primitive record of their human usage originates from China, about 1700 years ago (Yang et al., 2017). Initially, seaweeds were most often used for domestic purposes, whereas later, industrial uses such as production of food, confectionary, textile, pharmaceutical, dairy and paper, mostly as gelling, stabilising, thickening agents and fertilisers, emerged. Seaweeds are the only source for the production of agar, alginate and carrageenan. Other products such as mannitol, laminarin and fucoidin are also obtained from marine algae (Silas et al., 1987; Delaney et al., 2016). Today, the global seaweed industry is worth more than USD 6 billion per annum (approximately 12 million $t$ per annum in volume), of which $85 \%$ comprises food products for human consumption. Seaweed-derived extracts (carrageenan, agar and alginates) make up almost $40 \%$ of the world hydrocolloid market in terms of foods (FAO, 2018). According to FAO statistics (FAO, 2014, 2016), Eucheuma spp. and Kappaphycus alvarezii for carrageenans, Gracilaria spp. for agar,
Saccharina japonica (formerly Laminaria japonica), Undaria pinnatifida, Pyropia spp. (formerly Porphyra) and Sargassum fusiforme for algin and human food usage were the top seven most cultivated seaweed taxa. Among these seaweeds, the genus Gracilaria (Rhodophyta) has been demonstrated to be the most attractive candidate for intensive culture because of its ability to achieve high yields and produce commercially valuable products (Lapointe and Ryther, 1978; Kaladharan et al., 1993; Kaladharan et al., 1996; Troell et al., 1999; Wang, 2002; Yang et al., 2006). Gracilaria species, offer both high bioremediation efficiency (Zhou et al., 2006) and commercial value in established markets, such as agar-agar and has a strong demand in most Asian countries as a foodstuff since more than 300 years (Chopin et al., 2001; Fei, 2004; Neori et al., 2004; FAO, 2018). Agar-agar is mainly produced from Gracilaria spp., which is distributed worldwide, but grows mostly in tropical and subtropical waters (Yang et al., 2006). The global production of farmed Gracilaria spp. was 3.9 million $t$ in 2015 which ranks $3^{\text {rd }}$ after Eucheuma and Japanese kelp (FAO, 2018). China leads in production with a recorded harvest of 2.7 million $t$ of farmed Gracilaria in 2015 (FAO, 2018). So far 100 described species of Gracilaria are found globally (Bird 
and McLachlan, 1984; Liu, 1987; Fei et al., 1998). Among them in India, more than 30 marine species have been recorded and the main species cultivated is Gracilaria edulis (Rao, 1972; Kalimuthu et al., 1990) and cultivation of this species started since 1970 s by long-line ropes in submerged free-floating system in marine coastal waters (Krishnamurthy et al., 1975).

Currently, the main regional producers of food grade agar are Chile, Japan, the Republic of Korea and Taiwan Province of China (FAO, 2018). There are immense possibilities in India for emerging agar-processing industries, as the global demand of agar is increasing rapidly. The seaweed stocks from natural beds have become inadequate to meet industrial requirements and hence cultivation of these important resources has become necessary (Kalimuthu and Ramalingam, 1996). Seaweed culture in brackishwater environment requires a suitable species, which is adaptable and fast proliferating. The salinity tolerant $G$. tenuistipitata grows naturally in the tide fed brackishwater lagoons at Muttukadu perennially, but its standing crop in the natural habitat is low. It is abundant in patches throughout the sandy, shallow subtidal zone and often buried on hard substratum (Brawley and Fei, 1988). Although, this species is available perennially, it is available on a lower scale in summer season during March-May and is most abundant during post-monsoon period. In the present study, an experiment was conducted during post-monsoon period, in a lagoon and a pond at Muttukadu, Chennai, Tamil Nadu, to ascertain the basic water quality and nutrient requirements ( $\mathrm{N}$ and $\mathrm{P})$ and to estimate the initial stocking biomass intensity for optimum growth using two different methods viz., net bag and rope.

\section{Materials and methods}

\section{Collection of seaweed samples}

G. tenuistipitata samples were collected from shallow lagoon in Muttukadu, Chennai $\left(12^{\circ} 48^{\prime} 42.1^{\prime \prime} \mathrm{N}\right.$ and $80^{\circ} 14^{\prime} 39^{\prime \prime} \mathrm{E}$ ) during low tide period. Fresh seaweeds were transferred to the experimental station and cleaned thoroughly of epiphytes and encrusting organisms. Afterwards they were placed in FRP tanks containing saline water of $20 \mathrm{ppt}$, till the onset of the experiment.

Study sites

Culture trials of $G$. tenuistipitata were carried out in the same lagoon from where the seed stocks were collected and its nearby aquaculture pond at Muttukadu Experimental Station, ICAR-Central Institute of Brackishwater Aquaculture (ICAR-CIBA), Chennai, Tamil Nadu, India which is about 36.6 ha in total water spread area of 93 ha of Kovalam backwaters (Fig. 1). The experiments were carried out in the shallow water body of the lagoon and its nearby pond.

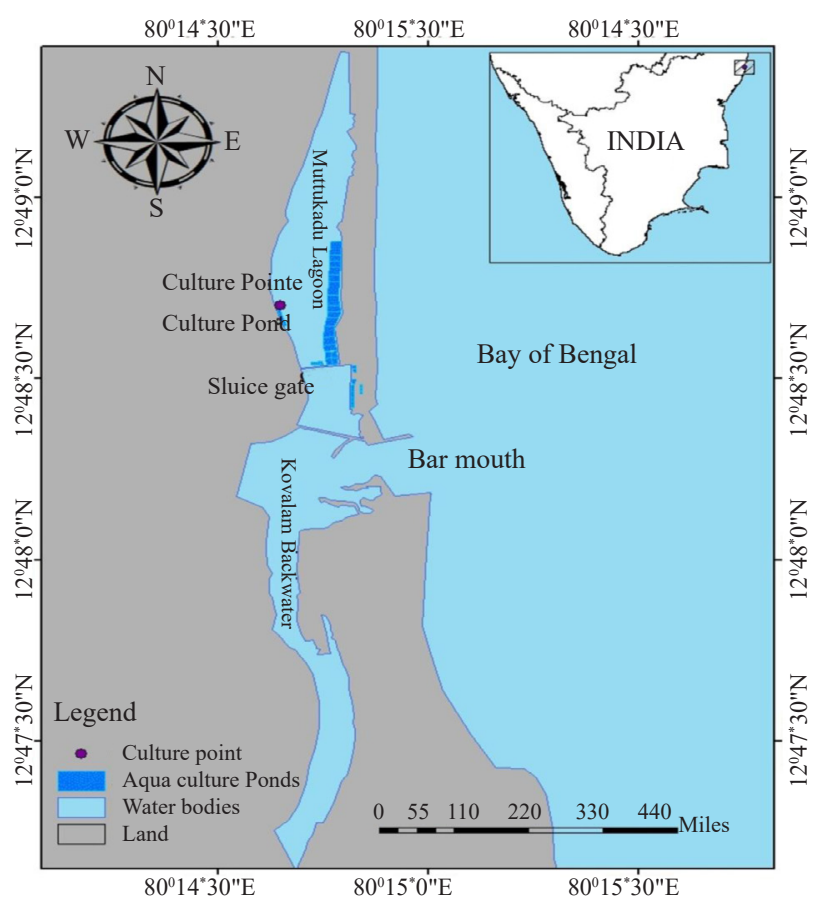

Fig. 1. Map showing culture location of G. tenuistipitata

\section{Experimental design}

A completely randomised design (CRD) experiment was carried out with two different culture methods viz. net bag and rope, with three different initial biomass intensity viz., 50, 100 and $200 \mathrm{~g}$ per meter.

The seaweed was attached to nylon ropes of $1 \mathrm{~m}$ length and $6 \mathrm{~mm}$ dia. Fronds weighing about $10 \mathrm{~g}$ were inserted every $20 \mathrm{~cm}$ to make $50 \mathrm{~g} \mathrm{~m}^{-1}$ (Fig. 2a). Similarly, for the other treatments viz., 100 and $200 \mathrm{~g} \mathrm{~m}^{-1}$, fronds were inserted@20 and 40 g respectively at every $20 \mathrm{~cm}$ distance. The ropes with Gracilaria were placed 0.2 to $0.3 \mathrm{~m}$ below the water surface and each end was tied to casuarina poles.

Net bags (Fig. 2b) of dimensions $1 \times 1 \times 1 \mathrm{~m}$ and mesh size $2 \mathrm{~mm}$ were suspended in the water with a depth of $0.3 \mathrm{~m}$ from the water surface to the bottom of the net bag and the corners of the net bags were tied to casuarina poles. The net bags were designed to prevent entry of herbivorous fishes into the bag.

\section{Assessment of water quality parameters and growth}

Water quality was analysed initially and at 20 day intervals for 60 days of culture in lagoon and for 20 days of culture in pond ecosystem. Water parameters such as 


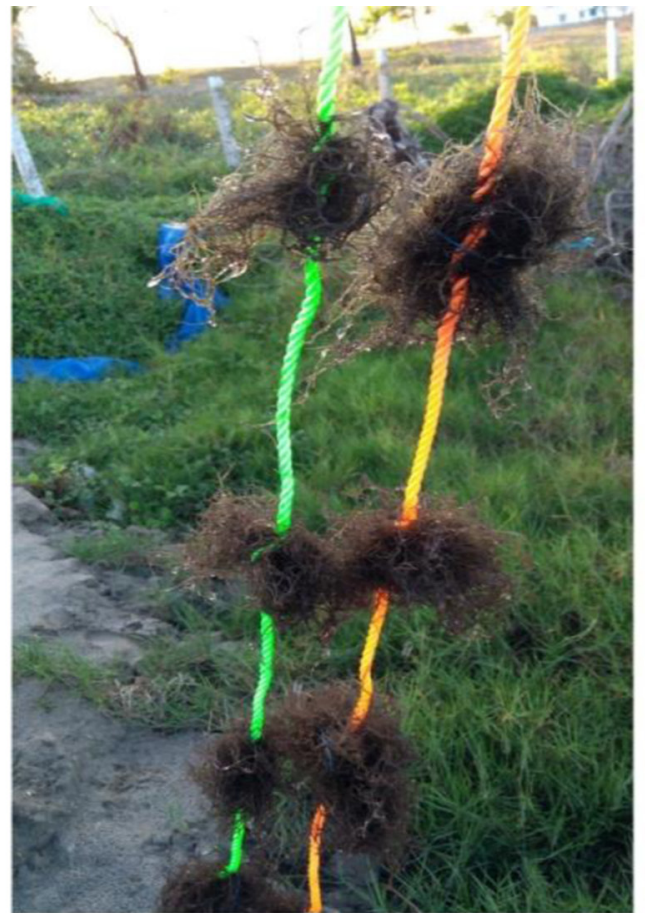

(a)

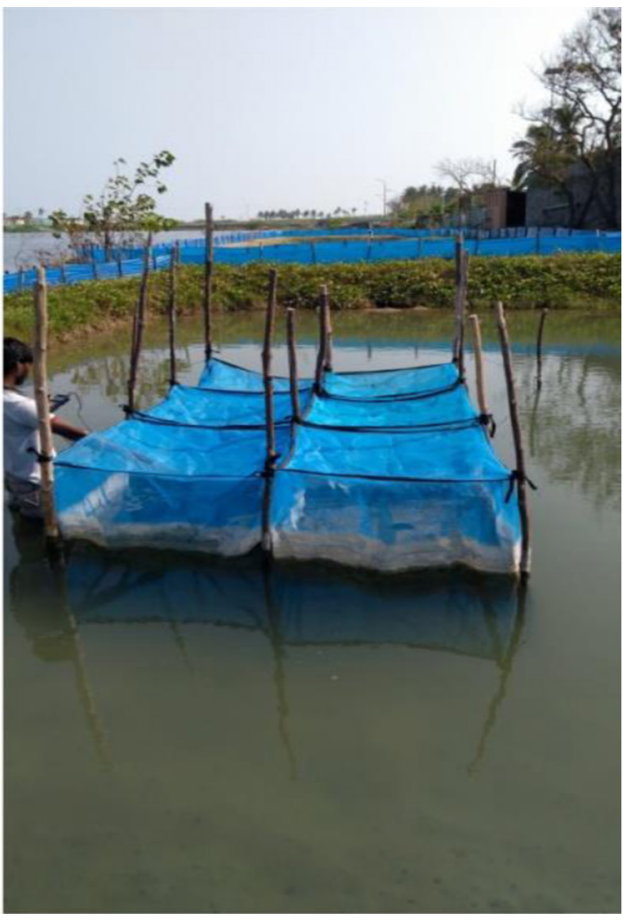

(b)

Fig. 2. (a) Rope and (b) net bag used for cultivating G. tenuistipitata

temperature (measured using a mercury thermometer), $\mathrm{pH}$ (measured using a pH-Scan-Eutech instruments, Singapore), salinity (measured using a hand refractometer), total ammonia nitrogen, TAN (estimated by Phenol hypochlorite method), $\mathrm{NO}_{2}-\mathrm{N}, \mathrm{NO}_{3}-\mathrm{N}$, phosphate-P $\left(\mathrm{PO}_{4}-\mathrm{P}\right)$, total alkalinity and dissolved oxygen (analysed following APHA, 1998) were monitored at 20 days interval during the experimental period. Specific growth rate (SGR) was calculated using the formula (Lobban and Harrison (1994):

SGR $\left(\%\right.$ day $\left.^{-1}\right)=(\ln$ final weight $-\ln$ initial weight $) /$ Days of culture $\times 100$

\section{Statistical analysis}

The data were statistically analysed using SPSS version 17.0 (SPSS Inc., Chicago, IL, USA). One-way ANOVA was used to determine the significance of SGR between seaweed initial biomass intensity for two different culture methods separately and for days of culture for rope method in lagoon ecosystem. If a main effect was significant, the ANOVA was followed by Tukey's HSD test. Independent samples t-test was used to determine the significance between two different culture methods and ecosystems. Pearson correlation between SGR and salinity during 20, 40 and 60 days was studied for the two culture methods. Level of significance was determined at $95 \%$ probability levels $(\mathrm{p} \leq 0.05)$ for all analyses.

\section{Results and discussion}

Water quality

During the experimental period, the salinity and temperature increased gradually in lagoon and it ranged between $19.7-25 \mathrm{ppt}$ and $28.57-31.02^{\circ} \mathrm{C}$ respectively (Table 1), since the experiment was conducted during post-monsoon season viz., January and February. Average dissolved oxygen and $\mathrm{pH}$ of the lagoon water ranged between 7.2-15.6 ppm and 8-8.4 respectively (Table 1) during the study period. In pond, salinity and temperature ranged between $11-13 \mathrm{ppt}$ and $28.67-29.53^{\circ} \mathrm{C}$ respectively, during the culture period (Table 2). Dissolved oxygen and $\mathrm{pH}$ of the pond water ranged between 4.62-6.18 ppm and 8.02-8.05 (Table 3). The water quality parameters were favourable for growth of $G$. tenuistipitata in both lagoon and pond. Earlier studies in Muttukadu backwater and pond ( $0.1 \mathrm{ha})$ for the culture of Gracilaria showed that post-monsoon season is conducive for its luxuriant proliferation (Bharathan, 1987). It has also been reported that $\mathrm{pH}$ above 8 is optimum for the growth of Gracilaria (Jayasankar et al., 2006). The average turbidity was found to be lesser than 30 NTU during the culture period with minimum of 12 NTU and maximum of 29 NTU in lagoon (Table 1) and initial 18.80 NTU to 3.65 NTU during 20 days of culture in pond ecosystem (Table 2). Lesser turbidity of water implies sufficient irradiance for photosynthesis 
Table 1 . Water quality parameters during culture of G. tenuistipitata in lagoon ecosystem

\begin{tabular}{lllll}
\hline Parameters & Initial & 20 days of culture & 40 days of culture & 60 days of culture \\
\hline Salinity (ppt) & $19.7 \pm 0.33$ & $22 \pm 0.00$ & $23 \pm 0.00$ & $25 \pm 0.00$ \\
Temperature $\left({ }^{\circ} \mathrm{C}\right)$ & $28.57 \pm 0.07$ & $28.00 \pm 0.04$ & $29.18 \pm 0.03$ & $31.02 \pm 0.04$ \\
$\mathrm{DO}(\mathrm{ppm})$ & $10.03 \pm 0.12$ & $15.62 \pm 0.13$ & $7.32 \pm 0.14$ & $7.27 \pm 0.12$ \\
$\mathrm{pH}$ & $8.11 \pm 0.02$ & $8.36 \pm 0.03$ & $8 \pm 0.04$ & $8.23 \pm 0.04$ \\
Turbidity (NTU) & $29.1 \pm 3.44$ & $22.63 \pm 1.05$ & $11.99 \pm 1.11$ & $23.23 \pm 1.18$ \\
Alkalinity (ppm) & $109.33 \pm 11.57$ & $106.67 \pm 3.45$ & $71.83 \pm 3.58$ & $63.67 \pm 2.40$ \\
$\mathrm{NH}_{4}-\mathrm{N}(\mathrm{ppm})$ & $0.03 \pm 0.006$ & $0.002 \pm 0.001$ & $0.24 \pm 0.039$ & $0.04 \pm 0.005$ \\
$\mathrm{NO}_{2}-\mathrm{N}(\mathrm{ppm})$ & $0.009 \pm 0.005$ & $0.003 \pm 0.001$ & $0.08 \pm 0.018$ & $0.001 \pm 0.000$ \\
$\mathrm{NO}_{3}-\mathrm{N}(\mathrm{ppm})$ & $0.07 \pm 0.009$ & $0.001 \pm 0.000$ & $0.06 \pm 0.014$ & $0.001 \pm 0.000$ \\
$\mathrm{PO}_{4}-\mathrm{P}(\mathrm{ppm})$ & $0.11 \pm 0.027$ & $0.03 \pm 0.004$ & $0.5 \pm 0.098$ & $0.07 \pm 0.018$ \\
\hline
\end{tabular}

Values represented as mean \pm S.E, $n=6$.

at 0.2 to $0.3 \mathrm{~m}$ depth. Total alkalinity of water was found high (109.33 ppm) during initial stocking and it decreased gradually as days of culture progressed in the lagoon (Table 1). Initial alkalinity of the pond water was $65 \mathrm{ppm}$ which increased to $90.53 \mathrm{ppm}$ in 20 days of culture (Table 2). Average $\mathrm{NH}_{4}-\mathrm{N}, \mathrm{NO}_{2}-\mathrm{N}, \mathrm{NO}_{3}-\mathrm{N}$ and $\mathrm{PO}_{4}-\mathrm{P}$ of lagoon water ranged from 0.002 to $0.24 \mathrm{ppm}, 0.001$ to 0.08 ppm, 0.001 to $0.07 \mathrm{ppm}$ and 0.03 to $0.11 \mathrm{ppm}$ respectively (Table 1). Initially $\mathrm{NO}_{3}-\mathrm{N}$ concentration was found to be maximum among dissolved inorganic nitrogen (DIN) but as days of culture progressed, the concentration of $\mathrm{NH}_{4}-\mathrm{N}$ concentration in the water increased, which is helpful for the growth of Gracilaria. This could be probably because of utilisation of ammonium, which is more metabolically energy-efficient, than nitrite and nitrate, as ammonium can be incorporated directly into amino acids (Lobban and Harrison, 1994; Liu et al., 2016). In the pond, $\mathrm{NH}_{4}-\mathrm{N}$, $\mathrm{NO}_{2}-\mathrm{N}, \mathrm{NO}_{3}-\mathrm{N}$ and $\mathrm{PO}_{4}-\mathrm{P}$ ranged between 0.06 and $0.065 \mathrm{ppm}, 0.001$ and $0.004 \mathrm{ppm}, 0.03$ and $0.06 \mathrm{ppm}$ and 0.001 and $0.02 \mathrm{ppm}$ respectively (Table 2 ). $\mathrm{NH}_{4}-\mathrm{N}$ was the main nitrogen source initially, which is favorable for the growth of Gracilaria. It was reported that a very low concentration of inorganic nitrogen in the form of $\mathrm{NH}_{4}-\mathrm{N}$

Table 2. Water quality parameters recorded during culture of $G$. tenuistipitata in pond ecosystem

\begin{tabular}{lll}
\hline Parameters & Initial & 20 days of culture \\
\hline Salinity $(p p t)$ & $11 \pm 0.001$ & $13 \pm 0.00$ \\
Temperature $\left({ }^{\circ} \mathrm{C}\right)$ & $28.67 \pm 0.33$ & $29.53 \pm 0.08$ \\
$\mathrm{DO}(\mathrm{ppm})$ & $6.18 \pm 0.03$ & $4.62 \pm 0.21$ \\
$\mathrm{pH}$ & $8.02 \pm 0.02$ & $8.05 \pm 0.06$ \\
Turbidity (NTU) & $18.80 \pm 0.94$ & $3.65 \pm 0.18$ \\
Alkalinity (ppm) & $65 \pm 4.02$ & $90.53 \pm 11.78$ \\
$\mathrm{NH}_{4}-\mathrm{N}(\mathrm{ppm})$ & $0.065 \pm 0.02$ & $0.06 \pm 0.01$ \\
$\mathrm{NO}_{2}-\mathrm{N}(\mathrm{ppm})$ & $0.001 \pm 0.0001$ & $0.004 \pm 0.00$ \\
$\mathrm{NO}_{3}-\mathrm{N}(\mathrm{ppm})$ & $0.0275 \pm 0.001$ & $0.06 \pm 0.02$ \\
$\mathrm{PO}_{4}-\mathrm{P}(\mathrm{ppm})$ & $0.001 \pm 0.0001$ & $0.02 \pm 0.01$ \\
\hline
\end{tabular}

Values represented as mean \pm S.E, $n=6$. and $\mathrm{NO}_{3}-\mathrm{N}(4 \mu \mathrm{m})$ is sufficient to maintain the growth of Gracilaria (Chaoyuan et al., 1993).

\section{Growth performance}

Average biomass production was higher in rope culture system than in net bag system in both the ecosystems. It was observed that during 20,40 and 60 days of culture, average seaweed biomass was 662,1744 and $2992.5 \mathrm{~g}$ in rope culture (Fig. 3) whereas it was 125.5, 188 and $215.5 \mathrm{~g}$ in net bag culture from initial biomass of 50.36 and $50.18 \mathrm{~g}$ respectively in lagoon ecosystem (Table 3).

In the pond, average biomass increased to $290 \mathrm{~g}$ (578\% of initial) in rope culture (Fig. 4) and $212.16 \mathrm{~g}$ (424\% of initial) in net bag culture, respectively (Table 4).

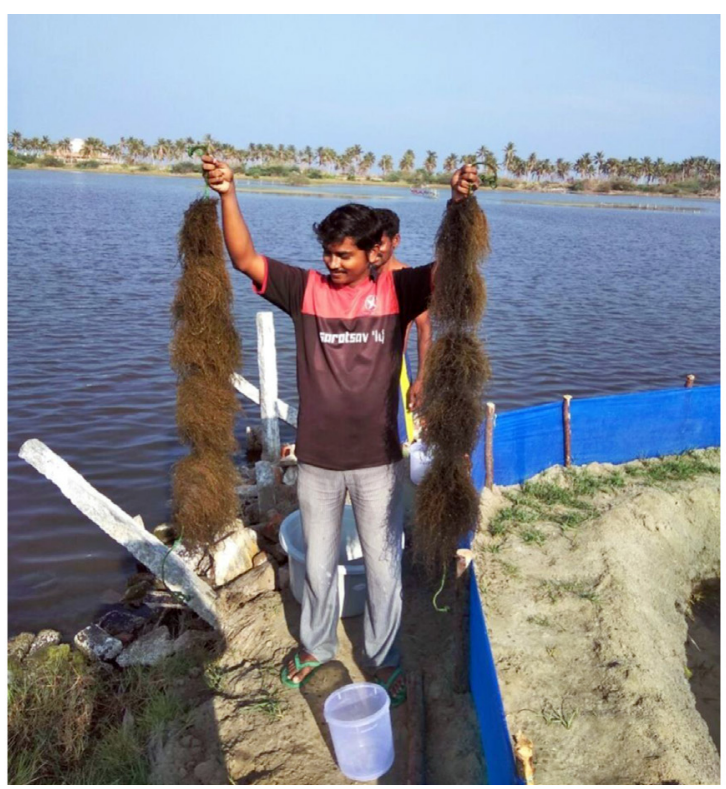

Fig. 3. G. tenuistipitata in rope culture system in Muttukadu Lagoon after 20 days of culture. 
Table 3. Biomass changes of G. tenuistipitata in different culture methods with different initial biomass intensity in Muttukadu Lagoon

\begin{tabular}{|c|c|c|c|c|c|c|c|}
\hline \multicolumn{4}{|c|}{ Rope culture } & \multicolumn{4}{|c|}{ Net-bag culture } \\
\hline Initial $\left(\mathrm{g} \mathrm{m}^{-1}\right)$ & 20 days $\left(\mathrm{g} \mathrm{m}^{-1}\right)$ & 40 days $\left(\mathrm{g} \mathrm{m}^{-1}\right)$ & 60 days $\left(\mathrm{g} \mathrm{m}^{-1}\right)$ & Initial $\left(\mathrm{g} \mathrm{m}^{-2}\right)$ & 20 days $\left(\mathrm{g} \mathrm{m}^{-2}\right)$ & 40 days $\left(\mathrm{g} \mathrm{m}^{-2}\right)$ & 60 days $\left(\mathrm{g} \mathrm{m}^{-2}\right)$ \\
\hline $50.36 \pm 0.017$ & $662 \pm 45.61$ & $1744.5 \pm 20.49$ & $2992.5 \pm 105.37$ & $50.18 \pm 0.087$ & $125.5 \pm 6.06$ & $188 \pm 31.66$ & $215.5 \pm 43.79$ \\
\hline $100.4 \pm 0.064$ & $899 \pm 60.62$ & $2305 \pm 297.40$ & $2879 \pm 285.79$ & $100.06 \pm 0.006$ & $193 \pm 13.28$ & $285 \pm 16.00$ & $227.5 \pm 19.34$ \\
\hline $200.42 \pm 0.003$ & $684.5 \pm 122.58$ & $1628 \pm 10.39$ & $2235 \pm 115.47$ & $200.48 \pm 0.075$ & $351 \pm 32.01$ & $534 \pm 66.46$ & $456.5 \pm 77.60$ \\
\hline
\end{tabular}

Data expressed as mean \pm S.E.

The t-test indicated that average SGR was significantly higher in rope system compared to net bag system in both lagoon (Fig. 5a-c) and pond ecosystems (Fig. 6).

Seaweeds get sufficient sunlight and better water motion in ropes compared to net bag system as rope is an open type culture system whereas net bag is a closed system which often gets clogged due to fouling on the net wall. Floating raft method (net or rope) was found appropriate and economically feasible for mass culture of Gracilaria edulis in Minicoy lagoon (Kaladharan et al., 1996). The essentiality of sufficient sun light and

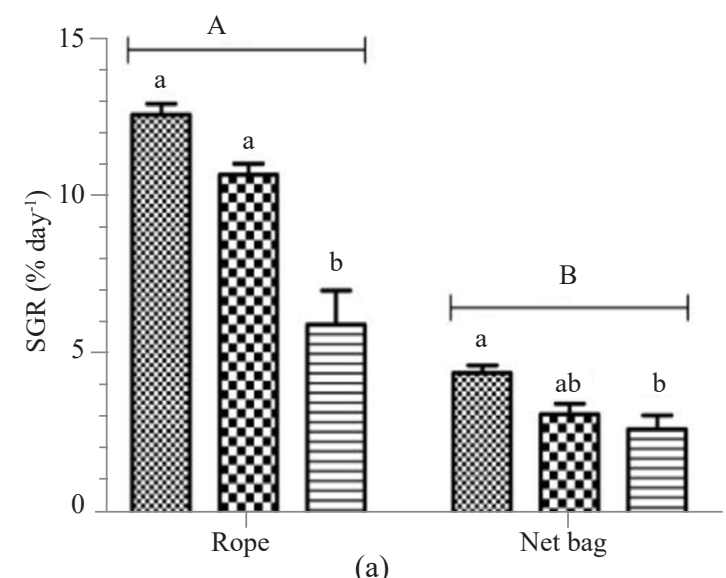

(a)

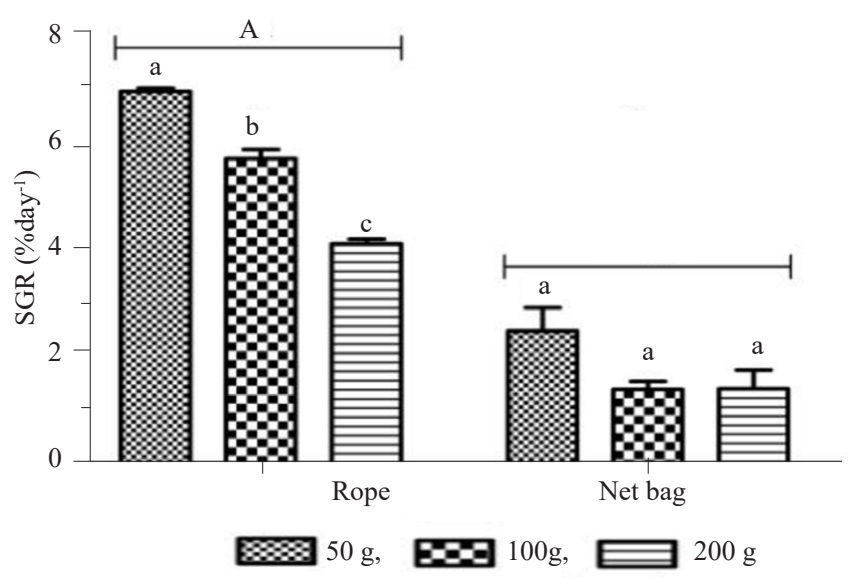

(c)

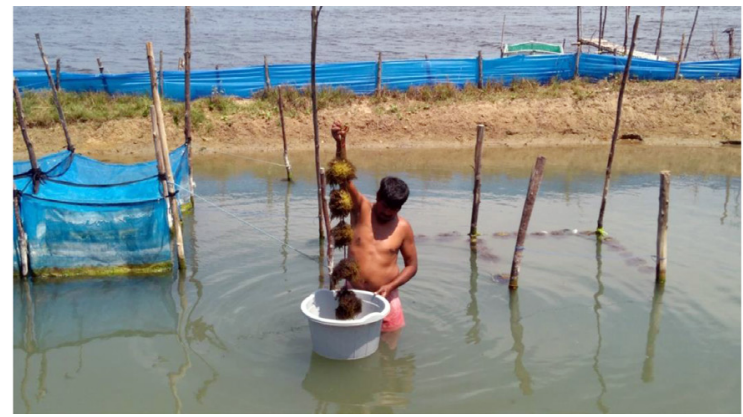

Fig. 4. G. tenuistipitata in rope culture system in Muttukadu pond ecosystem.

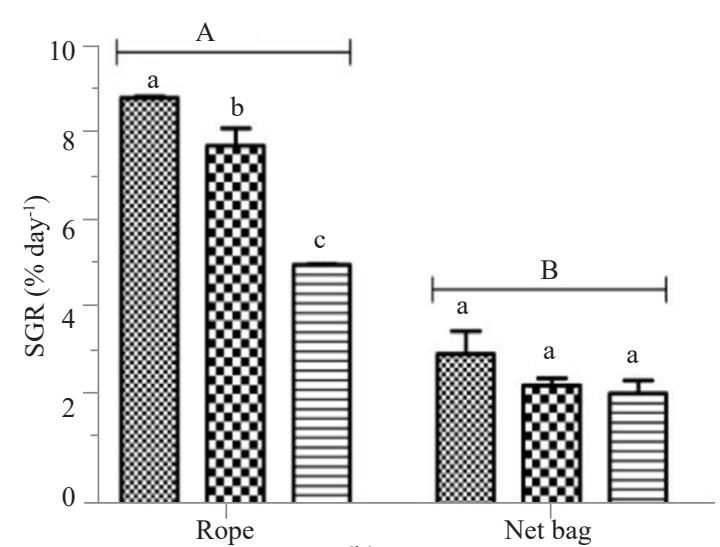

(b) 
Table 4. Growth of G. tenuistipitata in different culture systems with different initial biomass intensity in Muttukadu pond

\begin{tabular}{|c|c|c|c|c|c|}
\hline \multicolumn{3}{|c|}{ Rope culture } & \multicolumn{3}{|c|}{ Net-bag culture } \\
\hline $\begin{array}{l}\text { Initial biomass } \\
\left(\mathrm{g} \mathrm{m}^{-1}\right)\end{array}$ & $\begin{array}{l}\text { Final biomass } \\
\left(\mathrm{g} \mathrm{m}^{-1}\right)\end{array}$ & $\begin{array}{l}\text { Period of } \\
\text { growth (days) }\end{array}$ & $\begin{array}{l}\text { Initial biomass } \\
\left(\mathrm{g} \mathrm{m}^{-2}\right)\end{array}$ & $\begin{array}{l}\text { Final biomass } \\
\left(\mathrm{g} \mathrm{m}^{-2}\right)\end{array}$ & $\begin{array}{l}\text { Period of } \\
\text { growth (days) }\end{array}$ \\
\hline $50.13 \pm 0.017$ & $290 \pm 14.15$ & 20 & $50 \pm 0.00$ & $212.16 \pm 18.06$ & 20 \\
\hline $101.1 \pm 0.404$ & $514.75 \pm 13.57$ & 20 & $100 \pm 0.00$ & $322.92 \pm 1.73$ & 20 \\
\hline $203.56 \pm 1.801$ & $769.41 \pm 8.38$ & 20 & $200 \pm 0.00$ & $617.67 \pm 2.60$ & 20 \\
\hline
\end{tabular}

Data expressed as mean \pm S.E.

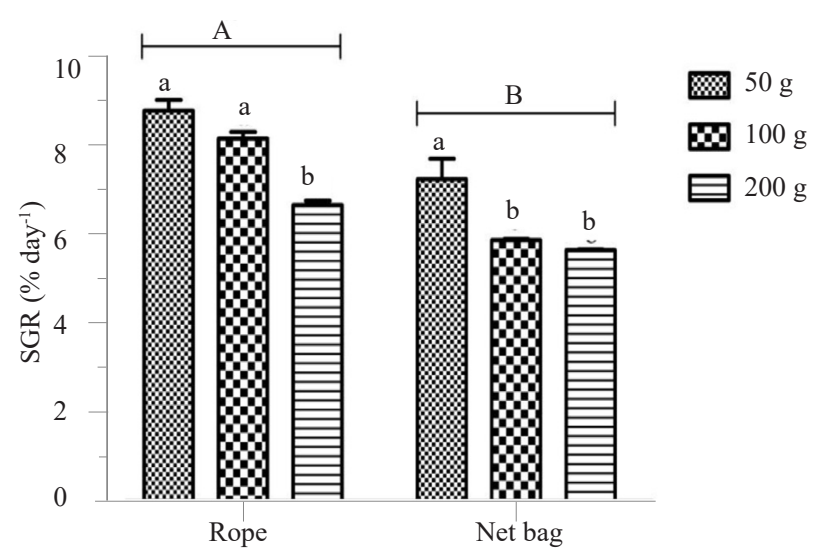

Fig. 6. SGR (mean \pm S.E., $\mathrm{n}=3$ ) of G. tenuistipitata for different initial biomass intensity in rope and net bag culture systems in pond. Different lower and upper case letters indicate statistical significance $(\mathrm{p}<0.05)$ among different seaweed biomass intensity and culture

water motion for optimising the growth of seaweed was demonstrated by Harrison and Hurd (2001) in tank culture system. Several authors reported the need for irradiance and water motion (rate of water exchange) for the growth of seaweeds (Friedlander et al., 1991; Gonan et al., 1993; Harrison and Hurd, 2001; Jayasankar et al., 2006). In the present study, growth of Gracilaria was better in rope culture than in net bag culture.

\section{Initial stocking biomass intensity}

With respect to initial biomass, SGR of Gracilaria was significant between different biomass intensity during culture trial. Post hoc analysis revealed that SGR was significantly higher with $50 \mathrm{~g} \mathrm{~m}^{-1}(12.86 \pm 0.35 \%)$ and $100 \mathrm{~g} \mathrm{~m}^{-1}(10.94 \pm 0.34 \%)$ biomass intensities compared to $200 \mathrm{~g} \mathrm{~m}^{-1}(6.14 \pm 1.09 \%)$ biomass intensity for 20 days of culture, whereas SGR for $50 \mathrm{~g} \mathrm{~m}^{-1}(8.86 \pm 0.03 \%$ and $6.81 \pm 0.06 \%$ ) of initial biomass was significantly higher than $100(7.83 \pm 0.37 \%$ and $5.58 \pm 0.17 \%)$ and $200 \mathrm{~g} \mathrm{~m}^{-1}$ $(5.24 \pm 0.016 \%$ and $4.02 \pm 0.09 \%)$ with rope method during 40 and 60 days of culture respectively, in lagoon ecosystem (Fig. 5a-c). Twenty days culture in pond ecosystem also showed similar result as 20 days culture in lagoon, in which SGR was significantly higher with
$50 \mathrm{~g} \mathrm{~m}^{-1}(8.76 \pm 0.24 \%)$ and $100 \mathrm{~g} \mathrm{~m}^{-1}(8.13 \pm 0.15 \%)$ than $200 \mathrm{~g} \mathrm{~m}^{-1}(6.65 \pm 0.098 \%)$ initial biomass in rope culture system. In net bag, the highest SGR $(7.23 \pm 0.46 \%$ and $4.59 \pm 0.24 \%$ ) was observed at $50 \mathrm{~g} \mathrm{~m}^{-2}$ initial biomass treatment and other two treatments viz., $100 \mathrm{~g} \mathrm{~m}^{-2}$ $(5.86 \pm 0.03$ and $3.26 \pm 0.35 \%)$ and $200 \mathrm{~g} \mathrm{~m}^{-2}(5.64 \pm 0.02$ and $2.8 \pm 0.45 \%)$ were not significantly different in pond and lagoon ecosystem respectively for 20 days of culture (Fig. 5a and 6). Overall, it was observed that SGR of Gracilaria decreased with increasing biomass intensity. One of the possible reasons is that sunlight becomes a limiting factor with higher density of seaweed, thus decreasing the efficiency of photosynthesis. Several authors agree with similar reasons for lower SGR due to higher biomass intensity (Lapointe and Tenore, 1981; DeBusk et al., 1986; Neori et al., 2004; Yang et al., 2006; Mao et al., 2009; Samocha et al., 2015).

\section{Days of culture}

Results showed that SGR was significantly higher at 20 days (12.86 and $10.94 \%$ ) compared to 40 (8.86 and $7.83 \%)$ and 60 (6.81 and 5.58\%) days of culture for both 50 and $100 \mathrm{~g} \mathrm{~m}^{-1}$ initial biomass treatment respectively in lagoon (Fig. 7a-b). Similar SGR (>12\%/day) of Gracilaria was recorded by Bharathan (1987) in Muttukadu lagoon after 30 days of culture. A negative correlation was observed between SGR and salinity during 20, 40 and 60 days of culture but it was not significant $(\mathrm{p}>0.05)$ (Table 5), implying noninterference of salinity in growth performance of $G$. tenuistipitata during the experiment. Salinity range of 19.7-25 ppt obtained during the culture period was conducive for the growth of the seaweed. Bharathan (1987) reported that salinity range between 17 and 25 ppt was suitable for the growth of Gracilaria in Muttukadu lagoon, while Jayasankar et al. (2006) reported a higher salinity range of $20-28$ ppt as suitable for the cultivation of Gracilaria in Muttukadu Lake. dela Pena (1996) recorded 10-25 ppt as the optimum salinity range for growth of $G$. tenuistipitata in Philippines.

The highest SGR $\left(>10 \%\right.$ day $\left.^{-1}\right)$ was obtained after 20 days of culture for 50 and $100 \mathrm{~g}$ culture treatments (Fig. 7a-b). Therefore, frequent harvest of the seaweed can be done at 20-days intervals within a year. The fronds can 
Table 5. Correlations and probability values between salinity and SGR during 20, 40 and 60 days of culture for the two culture methods at different initial biomass intensities

\begin{tabular}{|c|c|c|c|c|c|c|}
\hline \multirow{2}{*}{ Statistics } & \multicolumn{3}{|c|}{ Rope culture } & \multicolumn{3}{|c|}{ Net bag culture } \\
\hline & $50 \mathrm{~g} \mathrm{~m}^{-1}$ & $100 \mathrm{~g} \mathrm{~m}^{-1}$ & $200 \mathrm{~g} \mathrm{~m}^{-1}$ & $50 \mathrm{~g} \mathrm{~m}^{-2}$ & $100 \mathrm{~g} \mathrm{~m}^{-2}$ & $200 \mathrm{~g} \mathrm{~m}^{-2}$ \\
\hline Pearson $\mathrm{r}$ & -0.9313 & -0.9606 & -0.9947 & -0.9556 & -0.9934 & -0.9956 \\
\hline R square & 0.8672 & 0.9228 & 0.9894 & 0.9132 & 0.9868 & 0.9913 \\
\hline $\mathrm{p}$ value & 0.2374 & 0.1792 & 0.0656 & 0.1904 & 0.0732 & 0.0596 \\
\hline$p$ value summary & ns & ns & ns & ns & ns & ns \\
\hline
\end{tabular}

'ns' denotes non-significance ( $p>0.05)$.

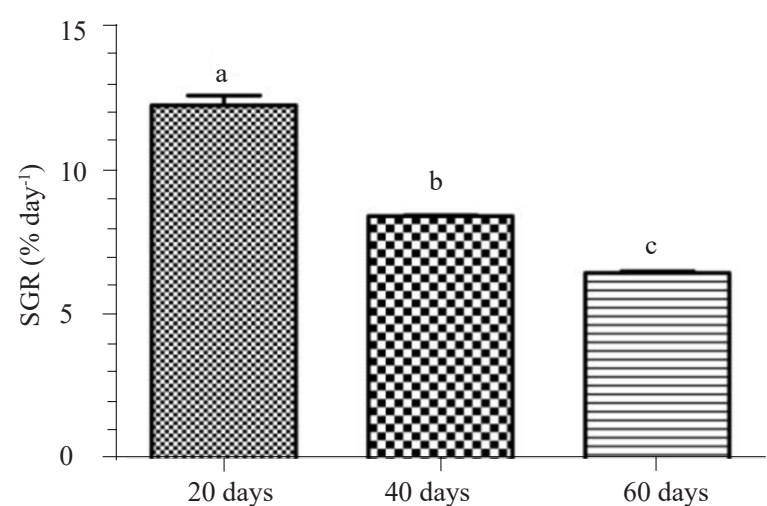

(a)

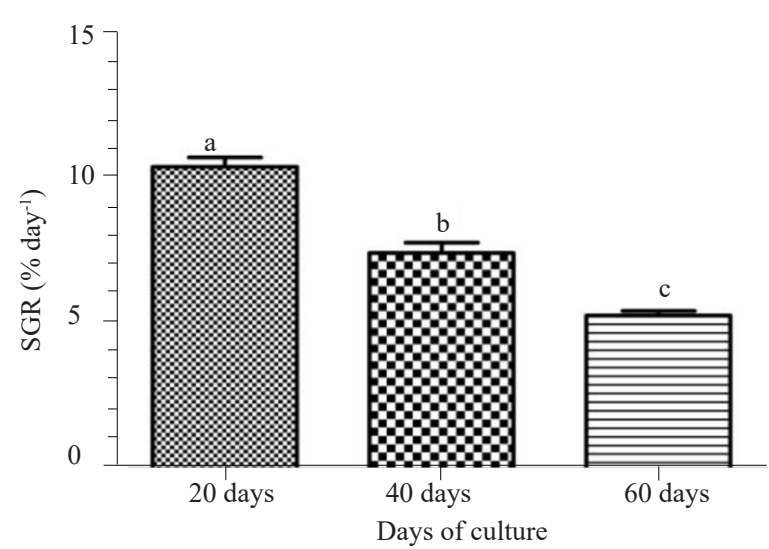

(b)

Fig. 7. Temporal variation of $\mathrm{SGR}($ mean \pm S.E., $\mathrm{n}=3$ ) of G. tenuistipitata for (a) $50 \mathrm{~g}$ and (b) $100 \mathrm{~g}$ initial biomass intensity. Different lower case letters indicate statistical significance $(p<0.05)$ between days of culture.

be clipped from the culture substratum, leaving the base as initial biomass for regrowth, to save the time and labour of replanting (Kaladharan et al., 1996).

\section{Lagoon and pond ecosystem}

Comparative results of growth performance for rope and net bag system separately between two different ecosystems are depicted in Fig. 8. It was found that mean SGR was significantly higher in lagoon $(9.98 \pm 1.06 \%)$ than in pond $(7.85 \pm 0.33 \%)$ ecosystem for rope culture technique (Fig. 8a). Continuous water current could be a possible reason for higher SGR in lagoon than in pond.
Mao et al. (2009) reported that static water may affect the growth of Gracilaria. Mean SGR was found significantly higher in pond $(6.24 \pm 0.28 \%)$ than in lagoon $(3.55 \pm 0.32 \%)$ for net bag culture technique (Fig. 8b).

Higher growth of epiphytes, barnacles and molluscs on the wall of the net bags in lagoon could be a reason for lesser SGR of Gracilaria in the net bag system in lagoon than in pond. Neori et al. (2004) reported that epiphytes
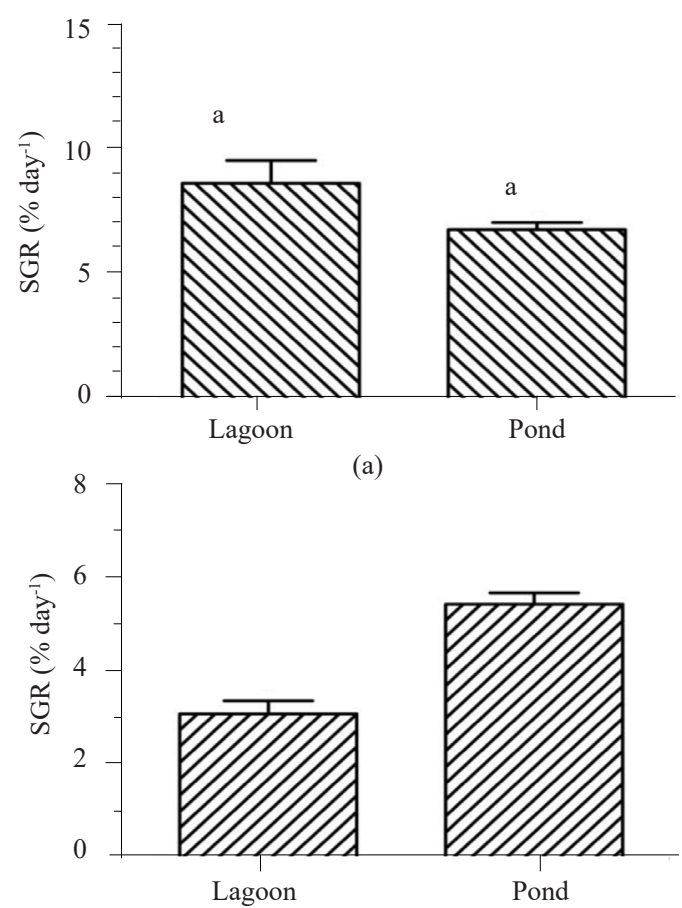

(b)

Fig. 8. SGR (mean \pm S.E., $\mathrm{n}=3$ ) of G. tenuistipitata in two different ecosystems (a) for rope culture and (b) net bag culture system. Different lower case letters indicate statistical significance $(p<0.05)$ between two different ecosystems.

are pest seaweeds and microalgae that use the cultured seaweed or the walls of the pond as substrates and compete for nutrients and light. Kaladharan et al. (1996) reported that Gracilaria edulis cultivation in Minicoy lagoon in cages was very effective in controlling grazers, but due to silt deposition and shading posed by excessive 
foliage on the mesh, frequent cleaning and maintenance was necessary and hence, it was found economically not feasible.

The results showed that $G$. tenuistipitata has been proliferating both in lagoon and in pond ecosystem with SGR greater than $8 \%$ in rope culture compared to net bag method in both ecosystems. From the results it was also observed that SGR was higher at lesser initial biomass intensity and 20 days of culture is considered to be optimum compared to 40 and 60 days of culture. Based on this study, initial biomass of $G$. tenuistipitata at $50-100 \mathrm{~g} \mathrm{~m}^{-1}$ was found best after 20 days of culture with rope method in lagoon than in pond ecosystem where brackishwater salinity regime. The study also revealed that net bag culture was quite effective at $50 \mathrm{~g} \mathrm{~m}^{-2}$ of initial biomass intensity in pond ecosystem when rope culture is not feasible. However, association between biomass production and agar content beyond 20 days of culture in both ecosystems needs to be investigated in order to check the economic feasibility of the methods. Nevertheless, the present study has indicated that G. tenuistipitata is potentially a fast growing species with higher SGR at low stocking intensity in brackishwater salinity regime. Hence, multiple crops may be obtained throughout the year with lesser input.

\section{Acknowledgements}

The authors are thankful to the Department of Science and Technology, Govt. of India for financial support and to the Director, ICAR-CIBA, Chennai for the facilities, support and encouragement.

\section{References}

APHA 1998. Standard methods for the examination of water and wastewater, $20^{\text {th }}$ edn. Washington DC, New York, USA, $1193 \mathrm{pp}$.

Bharathan, G. 1987. Experimental culture of Gracilaria at the Mariculture Centre, Muttukadu, Tamil Nadu. J. Mar. Biol. Ass. India, 29: 54-59.

Bird, C. J. and McLachlan, J. 1984. Taxonomy of Gracilaria: Evaluation of some aspects of reproductive structure. In: Bird, C. J. and Ragan, M. A. (Eds.), Proceedings of the Eleventh International Seaweed Symposium, 19 - 25 June 1983. Qingdao, China, p. 41-46. DOI:10.1007/ BF00027636.

Brawley, S. H. and Fei, X. G. 1988. Ecological studies of Gracilaria asiatica and Gracilaria lemaneiformis in Zhanshan Bay, Qingdao. Chin. J. Oceanol. Limn., 6: 22-34.

Buschmann, A. H., Camus, C., Infante, J., Neori, A., Israel, A., Hernandez-Gonzalez, M. C., Pereda, S. V., GomezPinchetti, J. L., Golberg, A., Tadmor-Shalev, N. and Critchleyh, A. T. 2017. Seaweed production:overview of the global state of exploitation, farming and emerging research activity. Eur. J. Phycol., 52(4):391-406. DOI: 10.1080/09670262.2017.1365175.

Chaoyuan, W., Li, R., Lin, G., Wen, Z., Dong, L., Zhang, J., Huang, X., Wei, S. and Lan, G. 1993.Some aspects of the growth of Gracilaria tenuistipitata in pond culture. Hydrobiologia, 260/261: 339-343.

Chopin, T., Buschmann, A. H., Halling, C., Troell, M., Kautsky, N., Neori, A., Kraemer, G., Zertuche-Gonzalez, J., Yarish, C. and Neefus, C. 2001. Integrating seaweeds into aquaculture systems: a key towards sustainability.J.Phycol.,37:975-986. doi.org/10.1046/j.1529-8817.2001.01137.x.

DeBusk, T. A., Blakeslee, M. and Ryther, J. H. 1986. Studies on the outdoor cultivation of Ulva lactuca. Bot. Mar., 29: 381-386. doi:10.1515/botm.1986.29.5.381.

Dela Pena, P. O. 1996. Philippines (Part II). Report of regional study and workshop on the taxonomy, ecology and processing of economically important red seaweeds. FAO/ NACA, Bangkok, Thailand, p. 152-158.

Delaney, A., Frangoudes, K. and Li, S. A. 2016. Society and seaweed: understanding the past and present. In:Fleurence, J. and Levine, I. (Eds.), Seaweed in health and disease prevention. Elsevier Academic Press, London, UK, p. 7-40.

Erlandson, J., Braje, T., Gill, K. and Graham, M. H. 2015. Ecology of the kelp highway: did marine resources facilitate human dispersal from North-east Asia to the Americas? J. Isl. Coast. Archaeol., 10: 392-411. doi.org/10.1080/1556 4894.2014.1001923.

FAO 2014. The state of world fisheries and aquaculture 2014 (SOFIA). Opportunities and challenges. Food and Agriculture Organisation, Rome, Italy, $243 \mathrm{pp}$.

FAO 2016. The state of world fisheries and aquaculture 2016 (SOFIA). Contributing to food security and nutrition for all. Food and Agriculture Organisation, Rome, Italy, 200 pp.

FAO 2018. The global status of seaweed production, trade and utilization. Globefish Research Programme. Food and Agriculture Organisation, Rome, Italy, 120 pp.

Fei,X.G. 2004. Solving the coastaleutrophication problemby large scale seaweed cultivation. Hydrobiologia, 512: 145-151. DOI: 10.1023/B:HYDR.0000020320.68331.ce.

Fei, X. G., Lu, S., Bao, Y., Wilkes, R. and Yarish, C. 1998. Seaweed cultivation in China. World Aquac., 29: 22-24.

Friedlander, M., Krom, M. D. and Ben-Amotz, A. 1991. The effect of the light and ammonium on growth, epiphytes and chemical constituents of Gracilaria conferta in outdoor cultures. Bot. Mar., 34: 161-166.

Gonan, Y., Kimmel, E. and Friedlander, M. 1993. Effect of relative water motion on photosynthetic rate of the red alga Gracilaria conferta. Hydrobiologia, 260/261: 493-498. DOI:10.1007/BF00049061.

Harrison, P. J. and Hurd, C. L. 2001. Nutrient physiology of seaweeds: Application of concepts to aquaculture. Cah. Biol. Mar., 42(1-2): 71-82. 
Jayasankar, R., Seema, C., Leelabhai, K. S. and Kanagam, A. 2006. Pond based grow out system of Gracilaria verrucosa. J. Aquac. Trop., 21: 161-167.

Kaladharan, P. and Chennuhhotla, V. S. K. 1993. Introduction and growth of Gracilaria edulis in Minicoy lagoon. Fish. Chimes, 13: 55

Kaladharan, P., Vijayakumaran, K. and Chennuhhotla, V. S. K. 1996. Optimisation of certain physical parameters for the mariculture of Gracilaria edulis (Gmelin) Silva in Minicoy lagoon (Laccadive Archipelago), Aquaculture, 139: 265-270.

Kalimuthu, S. and Ramalingam, J. R. 1996. India. Report on a regional study and workshop on the taxonomy, ecology and processing of economically important red seaweeds. Food and Agriculture Organisation, Bangkok, Thailand, p. 73-86.

Kalimuthu, S., Kaliaperumal, N., Ramalingam, J. and Chennubhotla, V. S. K. 1990. Present status of seaweed exploitation and seaweed industry in India. Mar. Fish. Inf. Serv. T\&E Ser., 103: 7-8.

Krishnamurthy, V., Raju, P. V. and Thomas, P. C. 1975. On augmenting seaweed resources of India. J. Mar. Biol. Ass. India, 17(2): 181-185.

Lapointe, B. E. and Ryther, J. H. 1978. Some aspects of the growth and yield of Gracilaria tikvahiae in culture. Aquaculture, 15: 185-193. DOI: 10.1016/0044-8486(78)90030-3.

Lapointe, B. E. and Tenore, K. R. 1981. Experimental outdoor studies with Ulva fasciata Delile, I. Interaction of light and nitrogen on nutrient uptake, growth and biochemical composition. J. Exp. Mar. Biol. Ecol., 53: 135-152. doi. org/10.1016/0022-0981(81)90015-0.

Liu, H., Wang, F., Wang, Q., Dong, S. and Tian, X. 2016. A comparative study of the nutrient uptake and growth capacities of seaweeds Caulerpa lentillifera and Gracilaria lichenoides. J. Appl. Phycol., 28(5): 3083-3089. DOI 10.1007/s10811-016-0858-8.

Liu, S. J. 1987. Study on the commercial cultivation of Gracilaria in South China. Chin. J. Oceanol. Limn., 5: 281-283.

Lobban, C. S. and Harrison, P. J. 1994. Seaweed ecology and physiology. Cambridge University Press, Cambridge, UK, $366 \mathrm{pp}$.

Mao, Y., Yang, H., Zhou, Y., Ye, N. and Fang, J. 2009. Potential of the seaweed Gracilaria lemaneiformis for integrated multi-trophic aquaculture with scallop Chlamys farreri in
North China. J. Appl. Phycol., 21: 649-656. DOI: 10.1007/ s10811-008-9398-1.

Neori, A., Chopin, T., Troell, M., Buschmann, A. H., Kraemer, G. P., Halling, C., Shpigel, M. and Yarish, C. 2004. Integrated aquaculture: rationale, evolution and state of the art emphasising seaweed biofiltration in modern mariculture, Aquaculture, 231: 361-391.

Samocha, T. M., Fricker, J., Ali, A. M., Shpigel, M. and Neori, A. 2015. Growth and nutrient uptake of the macroalga Gracilaria tikvahiae cultured with the shrimp Litopenaeus vannamei in an Integrated Multi-Trophic Aquaculture (IMTA) system. Aquaculture, 446: 263-271. doi.org/10.1016/j.aquaculture.2015.05.008.

Silas, E. G., Ramachandran, P. V. and Chennuhhotla, V. S. K. 1987. Seaweed research and utilisation in India. Bull. Cent. Mar. Fish. Res. Inst., 41: 1-2.

Troell, M., Ronnback, P., Halling, C., Kautsky, N. and Buschmann, A. 1999. Ecological engineering in aquaculture: use of seaweeds for removing nutrients from intense mariculture. J. Appl. Phycol., 11(1): 89-97. DOI: 10.1023/ A: 1008070400208 .

Rao, U. M. 1972. On the Gracilariaceae of the seas around India. J. Mar. Biol. Ass. India, 14(2): 671-696.

Wang, G. C. 2002. Isolation and purification of phycoerythrin from red alga Gracilaria verrucosa by combined expanded bed adsorption and ion exchange chromatography. Chromatographia, 56: 509-513.

Yang, L. E., Lu, Q. Q. and Brodie, J. 2017. A review of the bladed Bangiales (Rhodophyta) in China: history, culture and taxonomy. Eur. J. Phycol., 52: 1-13. DOI:10.1080/096 70262.2017.1309689.

Yang, Y. F., Fei, X. G., Song, J. M., Hu, H. Y., Wang, G. C. and Chung, I. K. 2006. Growth of Gracilaria lemaneiformis under different cultivation conditions and its effects on nutrient removal in Chinese coastal waters. Aquaculture, 254: $248-255$

Zhou, Y., Yang, H., Hu, H., Liu, Y., Mao, Y., Zhou, H., Xu, X. and Zhang, F. 2006. Bioremediation potential of the macroalga Gracilaria lemaneiformes (Rhodophyta) integrated into fed fish culture in coastal waters of north China. Aquaculture, 252: 264-276. DOI:10.1016/j.aquaculture.2005.06.046. 